JURNAL ILMIAH TEKNOLOGI INFORMASI DAN KOMUNIKASI (JTIK) VOL 12, No.2, September 2021, pp. 22 - 33

p-ISSN : 2087-0868 (media cetak)

e-ISSN : 2598-9707 (media online)

http://ejurnal.provisi.ac.id/index.php/JTIKP

\title{
SISTEM PENDUKUNG KEPUTUSAN PENGADAAN BAHAN BAKU PEMBUATAN ROTI MENGGUNAKAN METODE TOPSIS
}

\author{
Taufik Kurnialensya ${ }^{1}$, Sumaryanto ${ }^{2}$, Yuli Fitrianto ${ }^{3}$, \\ ${ }^{1}$ Komputer Dan Bisnis, Universitas STEKOM \\ Jl.Majapahit 605 Semarang, e-mail: taufik@stekom.ac.id \\ ${ }^{2}$ Komputer Dan Bisnis, Universitas STEKOM \\ Jl.Majapahit 605 Semarang, e-mail: sumaryanto@ stekom.ac.id \\ ${ }^{2}$ Komputer Dan Bisnis, Universitas STEKOM \\ Jl.Majapahit 605 Semarang, e-mail: yuli@ stekom.ac.id
}

\section{ARTICLE INFO}

Article history:

Received : 7 - September - 2021

Received in revised form : 7 - Oktober - 2021

Accepted : 11 - Oktober - 2021

Available online : 16 - Oktober - 2021

\begin{abstract}
CV.Tiara Bakery is a company engaged in the sale of bread in Semarang. Procurement of raw materials has an important role in the production process and requires good accuracy in selecting raw materials. The criteria used include delivery time, quality, quantity, price, warranty, brand. In using the Topsis method for a decision support system for the procurement of bread raw materials, it can be used for decision making recommendations and can be applied in companies. The PHP programming language can be implemented in making DSS for the procurement of bread raw materials. From the results of the assessment by experts or experts, it can be concluded that the validation results from experts show a value of 3.8 which is between $3.26-4.0$ which is classified as a very valid category. While the results of the assessment from the user can be concluded that the validation results from the user show a value of 3.0 which is between $2.51-3.25$ which is classified as a valid category.
\end{abstract}

Keywords: SPK, TOPSIS, raw material

\begin{abstract}
Abstrak
CV.Tiara Bakery adalah perusahaan yang bergerak di bidang penjualan roti di Semarang. Pengadaan bahan baku memiliki peranan penting dalam proses produksi dan membutuhkan ketelitian yang baik dalam memilih bahan baku. Kriteria yang digunakan meliputi waktu pengiriman, kualitas, kuantitas, harga, garansi, merek. Dalam menggunakan metode Topsis untuk sistem pendukung keputusan pengadaan bahan baku roti, dapat digunakan untuk rekomendasi pengambilan keputusan dan dapat diterapkan di perusahaan. Bahasa pemrograman PHP dapat diimplementasikan dalam pembuatan DSS untuk pengadaan bahan baku roti. Dari hasil penilaian ahli atau ahli dapat disimpulkan bahwa hasil validasi ahli menunjukkan nilai 3,8 yaitu antara 3,26 - 4,0 yang tergolong kategori sangat valid. Sedangkan hasil penilaian dari pengguna dapat disimpulkan bahwa hasil validasi dari pengguna menunjukkan nilai 3,0 yaitu antara 2,51 - 3,25 yang tergolong kategori valid.
\end{abstract}

Kata Kunci: SPK, TOPSIS, Bahan Baku.

\section{PENDAHULUAN}

Teknologi serta sistem informasi merupakan perpaduan antara teknologi informasi serta komunikasi yang menjalankan peranan utama. Dalam perkembangannya sistem informasi merupakan sebuah alat utama yang difungsikan sebagai penentu kemudahan dalam pengelolaan sumber data di perusahaan [4]-[6]. 
CV.Tiara Bakery merupakan perusahaan yang bergerak dibidang penjualan roti di kota Semarang. Pengadaan bahan baku mempunyai peranan penting dalam proses produksi dan butuh ketelitian yang baik dalam memilih bahan baku. Karena jika salah satu bahan produksi tidak tersedia akan berpengaruh besar dengan hasil dan kualitas produk yang dihasilkan.

CV.Tiara Bakery didalam pengadaan bahan baku, data belum terorganisasi dengan baik, sehingga pengerjaannya membutuhkan waktu yang lama dan tingkat kesalahan input data lebih sering terjadi. Pada CV.Tiara Bakery belum memiliki sebuah sistem yang berbentuk aplikasi berkaitan dengan pengambilan keputusan dalam pengadaan bahan baku.

Waktu yang diperlukan dalam pengadaan bahan baku dari supplier sampai bahan baku diterima oleh CV.Tiara Bakery memerlukan waktu tunggu, lama waktu tunggu tergantung dari ketersedian bahan baku supplier dan jarak tempuh lokasi supplier [7]-[9]. Waktu pengiriman bahan baku keperusahaan juga menjadi salah satu faktor penting dalam melakukan produksi roti.

Standar kuantitas bahan baku merupakan jumlah kuantitas bahan baku yang seharusnya dipakai dalam pengolahan roti. Penentuan standar kuatitas bahan baku dimulai dari penerapan spesifikasi roti, baik mengenai ukuran, bentuk, warna, karakteristik, pengolahan roti maupun mutunya [11]-[12].

CV.Tiara Bakery melakukan pengadaan bahan baku menghitung juga garansi yang diberikan oleh supplier atau distributor. Harga bahan baku merupakan salah satu aspek penting dalam pengadaan bahan baku roti. Bila harga bahan baku lebih murah maka akan memiliki dampak didalam biaya produksi dan pemberian harga penjualan roti [10].

Brand dari suatu produk terkenal bukan lagi menjadi hal yang utama didalam pemilihan bahan bahan baku roti. Karena perusahaan lebih melihat dari segi pertimbangan nilai (value consideration) daripada pertimbangan merk (brand consideration) [5].

Bagaimana merancang suatu sistem pendukung keputuan pengadaan bahan baku agar dapat menyajikan informasi dengan mudah, cepat, dan dapat menyimpan data secara terorganisasi di CV.Tiara Bakery. Bagaimana penerapan metode TOPSIS didalam sistem pendukung keputusan pengadaan bahan baku.

Technique for Order Preference by Similarity to Ideal Solution (TOPSIS) merupakan konsep yang mana alternatif terpilih yang terbaik tidak hanya memiliki jarak terpendek dari solusi ideal possitif, akan tetapi juga memiliki jarak terpanjang dari solusi ideal negatif. Kelebihan metode topsis diantaranya konsep algoritmanya sederhana dan mudah dipahami, perhitungan komputasinya lebih efisien dan cepat, mampu dijadikan sebagai pengukur kinerja alternatif dan juga alternatif keputusan dalam sebuah bentuk keluaran komputasi yang sederhana, dapat digunakan sebagai metode pengambilan keputusan yang lebih cepat dan lebih fleksibel [1]-[3].

Berdasarkan pemaparan yang dijabarkan diatas, perlu dibuatkan sistem pendukung keputusan pengadaan bahan baku roti dengan metode TOPSIS. Dalam pengadaan bahan baku roti menggunakan beberapa kriteria dalam pengelolaannya yaitu harga, kualitas, kuantitas, garansi, brand, waktu pengiriman.

\section{TINJAUAN PUSTAKA}

2.1. Sistem Pendukung Keputusan

Decision Support System didefinisikan merupakan suatu sistem yang sanggup membagikan keahlian baik keahlian pemecahan permasalahan ataupun keahlian pengkomunikasian buat permasalahan semiterstruktur. Secara spesial, DSS didefinisikan selaku suatu sistem yang menunjang kerja seseorang manager ataupun sekelompok manager dalam membongkar permasalahan semi terstruktur dengan metode membagikan data maupun usulan mengarah pada keputusan tertentu [12].

\subsection{TOPSIS (Technique For Others Reference by Similarity to Sempurna Solution)}

TOPSIS (Technique For Others Reference by Similarity to Sempurna Solution) merupakan salah satu tata cara pengambilan keputusan multikriteria yang awal kali diperkenalkan oleh Yoon serta Hwang( 1981). Tata cara TOPSIS ialah salah satu tata cara yang dapat menolong proses pengambilan keputusan yang maksimal buat menuntaskan permasalahan keputusan secara instan. Perihal ini diakibatkan sebab konsepnya simpel serta gampang dimengerti, komputasinya efektif serta mempunyai keahlian buat mengukur kinerja relatif dari alternatif- alternatif keputusan dalam wujud matematis yang simpel [2].

Secara universal, prosedur dari tata cara TOPSIS menjajaki langkah- langkah selaku berikut [6]:

a. Memastikan matriks keputusan yang ternormalisasi.

b. Menghitung matriks keputusan yang ternormalisasi terbobot.

c. Menghitung matriks pemecahan sempurna positif serta matriks pemecahan sempurna negatif.

d. Menghitung jarak antara nilai tiap alternatif dengan matriks pemecahan sempurna positif serta matrik pemecahan sempurna negatif.

e. Menghitung nilai preferensi buat tiap alternatif.

\subsection{Bahan Baku}


Bahan baku adalah bahan pokok yang dibutuhkan untuk usaha. Dalam usaha berbentuk produksi roti bahan baku yang diperlukan adalah bahan yang digunakan untuk produk. Jika dalam usaha dibidang jasa yang digunakan bahan bakunya adalah bahan penunjang untuk pengerjaan suatu pekerjaan [11].

Faktor yang memiliki pengaruh dari sebuah bahan baku, cara pembelian bahan baku, harga bahan baku, perkiraan penggunaan bahan baku, biaya persedian bahan baku, kebijakan pembelian bahan baku, penggunaan bahan baku secara realtime, waktu tunggu pemesanan bahan baku, pembelian kembali, pengamanan persediaan, biaya penyimpanan.

\subsection{MySQL}

MySQL adalah salah satu jenis databaseserver yang sangat terkenal dan banyak digunakan untuk membangun aplikasi web yang menggunakan databasesebagai sumber dan pengelolaan datanya. Kepopuleran MySQL antara lain karena MySQL menggunakan SQL (structure query language) sebagai bahasa dasar untuk mengakses database-nya sehingga mudah untuk digunakan, kinerja query cepat, dan mencukupi untuk kebutuhan database perusahaan - perusahaan skala menengah - kecil [14].

\subsection{PHP}

PHP (Hypertext Preprocessor) ini merupakan bahasa yang hanya dapat berjalan pada server dan hasilnya dapat ditampilkan pada client. PHP adalah produk (open source) yang dapat digunakan secara gratis tanpa harus membayar untuk menggunakannya.

Fasilitas PHP yang paling kuat dan pasti adalah integrasinya dengan mesin database yang membuat halaman dengan dukungan database dengan mudah. PHP termasuk dalam HTML-embedded, artinya code php dapat disisipkan pada sebuah halaman HTML. Untuk mengetahui bahwa baris - baris HTML merupakan suatu script php maka digunakan pasangan tag [15].

\subsection{Flowchart}

Flowchart adalah bagan - bagan yang mempunyai arus yang menggambarkan langkah - langkah penyelesaian suatu masalah. Flowchart disusun dengan simbol. Simbol ini dipakai sebagai alat bantu menggambarkan proses didalam program. Simbol di dalam flowchart dapat dibedakan menjadi tiga bagian, yaitu, flow direction symbol, processing symbol, input output symbol [15].

\subsection{Normalisasi}

Normalisasi adalah proses pengelompokkan data kedalam bentuk tabel atau relasi atau file untuk menyatakan entitas dan hubungan mereka sehingga terwujud satu bentuk database yang mudah untuk dimodifikasi. Bentuk - bentuk normalisasi adalah sebagai berikut, bentuk tidak normal, normalisasi 1 , normalisasi 2, normalisasi 3 [8].

\section{METODOLOGI PENELITIAN}

Dalam pendekatan ini menggunakan metode R \& D (Research and Development) Dalam penelitian ini digunakan 6 langkah yaitu [14] :

a. Research and information collecting.

Melakukan wawancara dengan pihak perusahaan untuk mendapatkan data berkaitan dengan proses pengadaan bahan baku roti. Penulis juga melakukan studi literatur untuk mendapatkan teori yang berkaitan dengan sistem yang akan dikembangkan.

b. Planning

Menyusun seluruh peralatan yang dibutuhkan terkait dengan desain program sistem pendukung keputusan pengadaan bahan baku, seperti membuat spesifikasi produk dan membuat jadwal kegiatan.

c. Develop preliminary form

Membuat desain sistem informasi produk berupa, Data Flow Diagram, desain basis data, normalisasi, Entity Relational Diagram. [2]

\section{Diagram Konteks}


Keterangan :

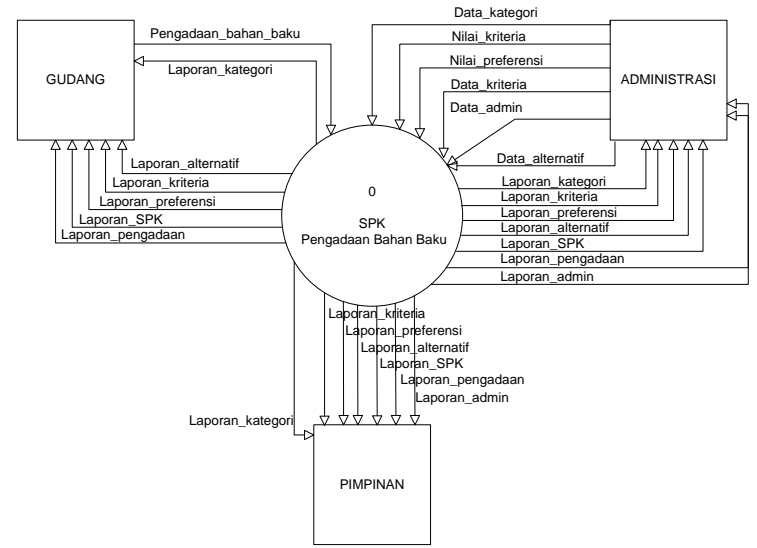

Gambar 1. Diagram Konteks

a. Gudang melakukan pengiriman data pengadaan bahan baku ke dalam sistem.

b. Administrasi mengirimkan data nilai kriteria, nilai preferensi, data kriteria, data alternatif, dan data admin ke dalam sistem. Administrasi menerima laporan kriteria, laporan preferensi, laporan alternatif, laporan pengadaan, laporan spk, laporan admin.

c. Pimpinan menerima menerima laporan kriteria, laporan preferensi, laporan alternatif, laporan pengadaan, laporan spk, laporan admin.

\section{Data Flow Diagram Level 0}

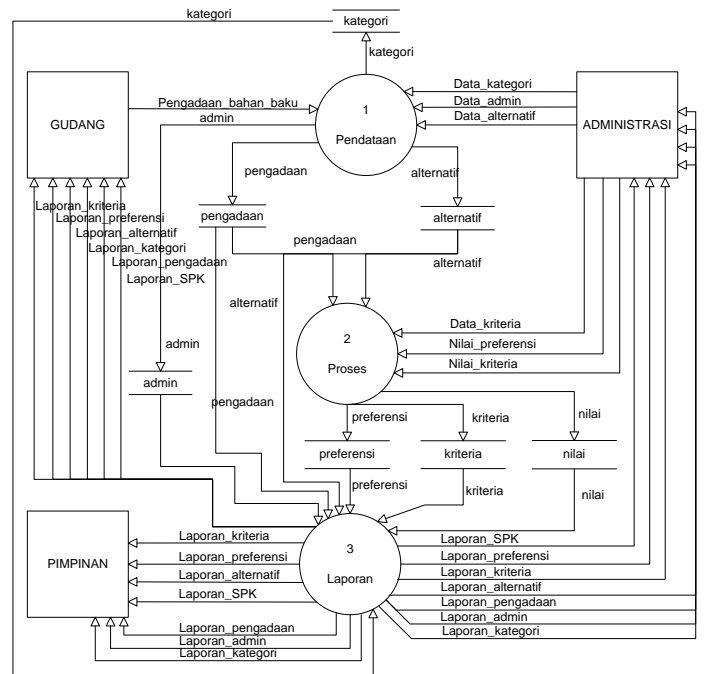

Gambar 2. Data Flow Diagram Level 0

Keterangan :

a. Dari gudang masuk ke sistem pendataan berupa data pengadaan bahan baku.

b. Dari administrasi memberikan masukan data sistem pendataan berupa data admin, data alternative dan data kategori, sistem pendataan akan disimpan sebagai tabel admin, kategori dan tabel alternatif.

c. Dari sistem pendataan akan masuk kedalam sistem proses yang mana sistem proses akan memproses data masukan berupa pengadaan, alternatif.

d. Dari data pendataan pegadaan dan alternatif, masuk kedalam sistem proses.

e. Sistem proses akan mengolah data alternatif, data kriteria, data preferensi dan kriteria dalam proses perhitungan matriks. Pada sistem laporan menerima data dari pengadaan, alternatif, preferensi, admin, kriteria, nilai.

f. Dari data yang masuk akan diproses menjadi laporan pengadaan, laporan alternatif, laporan preferensi, laporan admin, laporan kriteria, laporan spk.

\section{Normalisasi}




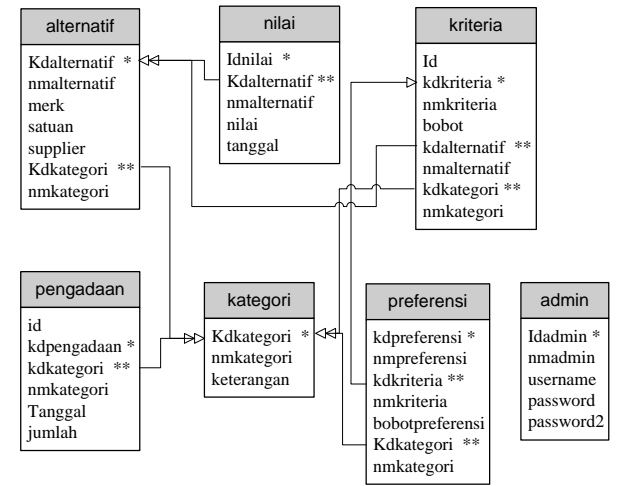

Gambar 3. Normalisasi

Gambar 3 menunjukkan hubungan antar tabel yang saling mempengaruhi satu dengan lainnya. Hubungan antar tabel wajib memiliki atribut primary key dan secondary key pada tabel relasinya.

\section{ERD (Entity Relation Diagram)}

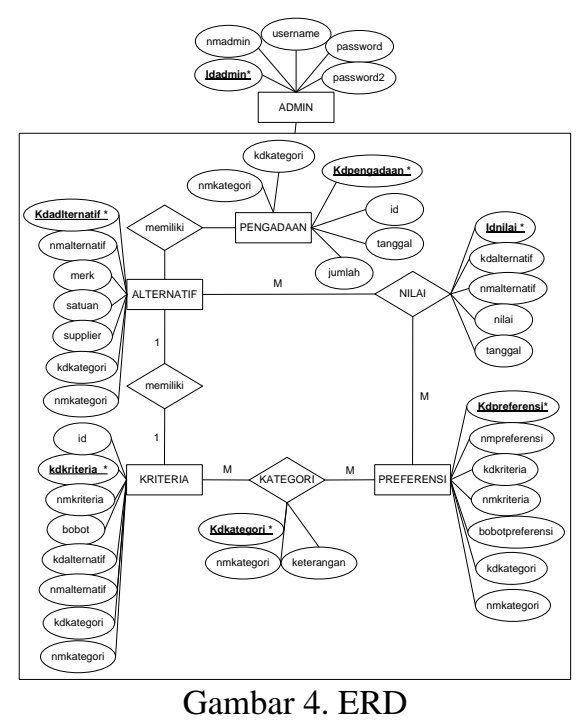

Dari analisa yang terjadi dari ERD tersebut maka muncul beberapa Pada gambar 4 menerangkan bahwa terdapat empat entitas diantaranya kriteria, preferensi, alternatif, dan nilai. Hubungan antara preferensi dan kriteria yang berelasi one to one, hubungan antara kriteria dengan alternatif yang berelasikan one to one, hubungan antara alternatif dengan penilaian yang berelasi many to many.

a. Preliminary field testing

Melakukan uji validasi desain sistem pendukung keputusan pengadaan bahan baku, oleh pakar untuk dapat diketahui kekurangannya.

\section{b. Main product revision}

Melakukan perbaikan terhadap desain awal sistem pendukung keputusan pengadaan bahan baku menggunakan metode TOPSIS di CV.Tiara Bakery Semarang yang dihasilkan berdasarkan hasil ujicoba awal, jika masih ditemukan kekurangan akan diperbaiki sesuai petunjuk dari pakar.

c. Main field testing

Setelah desain sistem dinyatakan valid oleh pakar, kemudian dibuat source code program. Produk akan diuji lapangan oleh user di CV.Tiara Bakery Semarang.

\section{HASIL DAN PEMBAHASAN}

\subsection{Prosedur Metode TOPSIS}

Dalam pengembangan dengan metode TOPSIS terdapat beberapa prinsip dasar yang harus dilakukan :

a. Menganalisa penyelesaian masalah.

Untuk menentukan kriteria penyelesaian masalah, dimana kriteria yang digunakan meliputi lama waktu pengiriman, kualitas, kuantitas, harga, garansi, brand.

b. Menentukan $\mathrm{n}$ buah alternatif dan $m$ buah kriteria kedalam suatu matriks.

Tabel 1. Nilai Alternatif 


\begin{tabular}{lcccccc}
\hline \multicolumn{1}{c}{ Alternatif } & C1 & C2 & C3 & C4 & C5 & C6 \\
\hline Bahan Baku 1 & 5 & 4 & 4 & 8 & 4 & 5 \\
Bahan Baku 2 & 4 & 5 & 3 & 3 & 5 & 6 \\
Bahan Baku 3 & 5 & 5 & 5 & 5 & 5 & 7 \\
Nilai Pangkat & 66 & 66 & 50 & 98 & 66 & 110 \\
\hline
\end{tabular}

Keterangan :

$\mathrm{C} 1$ = waktu kirim

$\mathrm{C} 2=$ kualitas

C3 = kuantitas

$\mathrm{C} 4=$ harga

C5 = garansi

C6 $=$ brand

Terdapat alternatif bahan baku 1, bahan baku 2, dan bahan baku 3. Setiap bahan baku memiliki nilai dari kriteria. Kriteria waktu kirim pada alternatif bahan baku 1 nilainya 5, Kriteria waktu kirim pada alternatif bahan baku 2 nilainya 4, Kriteria waktu kirim pada alternatif bahan baku 3 nilainya 5. Nilai pangkat dari kriteria waktu kirim adalah 66, yang didapat dari total nilai kriteria waktu kirim pangkat 2 dari masingmasing alternatif.

Contoh $:\left(5^{\wedge} 2\right)+\left(4^{\wedge} 2\right)+\left(5^{\wedge} 2\right)=25+16+25=66$

c. Matriks keputusan normalisasi

Tabel 2. Nilai matriks keputusan normal

\begin{tabular}{lllcccc}
\hline \multicolumn{1}{c}{ Normalisasi R } & C1 & C2 & C3 & C4 & C5 & C6 \\
\hline Bahan Baku 1 & 25 & 16 & 16 & 64 & 16 & 25 \\
Bahan Baku 2 & 16 & 25 & 9 & 9 & 25 & 36 \\
Bahan Baku 3 & 25 & 25 & 25 & 25 & 25 & 49 \\
Total Nilai & 66 & 66 & 50 & 98 & 66 & 110 \\
\hline
\end{tabular}

Keterangan :

Baris bahan baku 1 pada kolom kriteria waktu kirim memiliki nilai 25 didapatkan dari hasil $5^{\wedge} 2=25$. Nilai 5 merupakan nilai dari kriteria waktu kirim dari alternatif bahan baku 1, pada tabel 2 nilai alternatif.

d. Menentukan nilai solusi ideal positif (PIS) dan nilai solusi ideal negatif (NIS)

Tabel 3. Nilai matriks keputusan normal

\begin{tabular}{lcccccc}
\hline \multicolumn{1}{c}{ Normalisasi Y Positif } & C1 & C2 & C3 & C4 & C5 & C6 \\
\hline Bahan Baku 1 & 0.38 & 0.24 & 0.32 & 0.65 & 0.24 & 0.23 \\
Bahan Baku 2 & 0.24 & 0.38 & 0.18 & 0.09 & 0.38 & 0.33 \\
Bahan Baku 3 & 0.38 & 0.38 & 0.50 & 0.26 & 0.38 & 0.45 \\
Nilai Tertinggi & 0.38 & 0.38 & 0.50 & 0.65 & 0.38 & 0.45 \\
\hline
\end{tabular}

Keterangan :

Pada baris bahan baku 1 kolom waktu kirim terdapat nilai 0.379 , nilai ini didapat dari 25 / $66=0.379$.

25 adalah nilai kriteria waktu kirim, dan 66 adalah nilai total pangkat pada tabel 3.2 nilai matriks keputusan normal.

Pada baris nilai tertinggi kolom waktu kirim terdapat nilai 0.379 merupakan nilai tertinggi dari beberapa nilai alternatif pada kriteria waktu kirim.

Tabel 4. Nilai matriks keputusan normal

\begin{tabular}{lcccccc}
\hline \multicolumn{1}{c}{ Nilai Normalisasi Y Negatif } & C1 & C2 & C3 & C4 & C5 & C6 \\
\hline Bahan Baku 1 & 0.38 & 0.24 & 0.32 & 0.65 & 0.24 & 0.23 \\
Bahan Baku 2 & 0.24 & 0.38 & 0.18 & 0.09 & 0.38 & 0.33 \\
Bahan Baku 3 & 0.38 & 0.38 & 0.50 & 0.26 & 0.38 & 0.45 \\
Nilai Terendah & 0.24 & 0.24 & 0.18 & 0.09 & 0.24 & 0.23 \\
\hline
\end{tabular}

Keterangan :

Pada baris bahan baku 1 kolom waktu kirim terdapat nilai 0.38 , nilai ini didapat dari 25 / $66=0.38$.

25 adalah nilai kriteria waktu kirim, dan 66 adalah nilai total pangkat pada tabel 2 nilai matriks keputusan normal.

Pada baris nilai tertinggi kolom waktu kirim terdapat nilai 0.24 merupakan nilai terendah dari beberapa nilai alternatif pada kriteria waktu kirim.

e. Menentukan nilai preferensi untuk setiap alternatif $(\mathrm{Ci})$

Tabel 5. Nilai Separation Measure

\begin{tabular}{ccccccc}
\hline Preferensi & C1 & C2 & C3 & C4 & C5 & C6 \\
\hline Bobot Preferensi & 8 & 9 & 10 & 5 & 10 & 7 \\
\hline
\end{tabular}

Keterangan :

Nilai preferensi merupakan nilai dari bobot kepentingan antara tiap-tiap kriteria.

f. Menghitung separation measure. 
Yaitu pengukuran jarak antara suatu nilai alternaatif terhadap nilai ideal positif dan nilai ideal negatif

Tabel 6. Nilai Separation Measure Positif

\begin{tabular}{lccccccc}
\hline $\begin{array}{c}\text { Bobot Normalisasi Matrik } \\
\text { Ideal Positif }\end{array}$ & C1 & C2 & C3 & C4 & C5 & C6 & SMP \\
\hline Bahan Baku 1 & 1.15 & 0.83 & 1.60 & 2.13 & 0.92 & 0.71 & 7.33 \\
Bahan Baku 2 & 0.73 & 1.29 & 0.90 & 0.30 & 1.43 & 1.02 & 5.68 \\
Bahan Baku 3 & 1.15 & 1.29 & 2.50 & 0.83 & 1.43 & 1.39 & 8.60 \\
\hline
\end{tabular}

Keterangan :

SMP = Separation Measure Positif

Pada baris bahan baku 1 kolom waktu kirim terdapat nilai 1.15, merupakan nilai yang didapat dari nilai normalisasi Y positif kali nilai tertinggi, dikalikan nilai bobot preferensi.

$(0.38 * 0.38) * 8=1.15$

Pada baris bahan baku 1, kolom separation measure positif terdapat nilai 7.33 merupakan penjumlahan dai nilai kriteria di setiap alternatif.

$1.15+0.83+1.60+2.13+0.92+0.71=7.33$

Tabel 7. Nilai Separation Measure Negatif

\begin{tabular}{lccccccr}
\hline $\begin{array}{c}\text { Bobot Normalisasi Matriks } \\
\text { Ideal Negatif }\end{array}$ & C1 & C2 & C3 & C4 & C5 & C6 & SMN \\
\hline Bahan Baku 1 & 0.73 & 0.53 & 0.58 & 0.30 & 0.59 & 0.36 & 3.09 \\
Bahan Baku 2 & 0.47 & 0.83 & 0.32 & 0.04 & 0.92 & 0.52 & 3.10 \\
Bahan Baku 3 & 0.73 & 0.83 & 0.90 & 0.12 & 0.92 & 0.71 & 4.21 \\
\hline
\end{tabular}

Keterangan :

SMN = Separation Measure Negatif

Pada baris bahan baku 1 kolom waktu kirim terdapat nilai 0,73 merupakan nilai yang didapat dari nilai normalisasi Y negatif kali nilai teredah, dikalikan nilai bobot preferensi.

$(0.38 * 0.24) * 8=0.73$

Pada baris bahan baku 1, kolom separation measure negatif terdapat nilai 3.089 merupakan penjumlahan dai nilai kriteria di setiap alternatif.

$0.73+0.53+0.58+0.30+0.59+0.36=3.09$

g. Menghitung nilai perangkingan

Tabel 8. Nilai Perangkingan

\begin{tabular}{lc}
\hline \multicolumn{1}{c}{ Alternatif } & Nilai \\
\hline Bahan Baku 1 & 0.296 \\
Bahan Baku 2 & 0.353 \\
Bahan Baku 3 & 0.328 \\
\hline
\end{tabular}

Keterangan :

Nilai 0.296 adalah nilai dari :

$3.09 /(3.09+7.35)=0.296$

Dari nilai perangkingan pada tabel 8, maka nilai alternatif bahan baku 2 yang paling tinggi.

\subsection{Hasil Pengembangan}

a. Form Kategori Bahan Baku

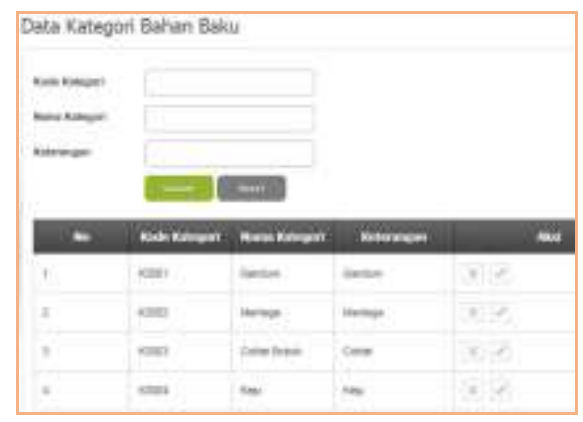

Keterangan :

Gambar 5. Form Data Kategori

Form kategori bahan baku merupakan form yang digunakan untuk mengelola data kategori bahan baku roti.

b. Form Alternatif Bahan Baku 
Keterangan :

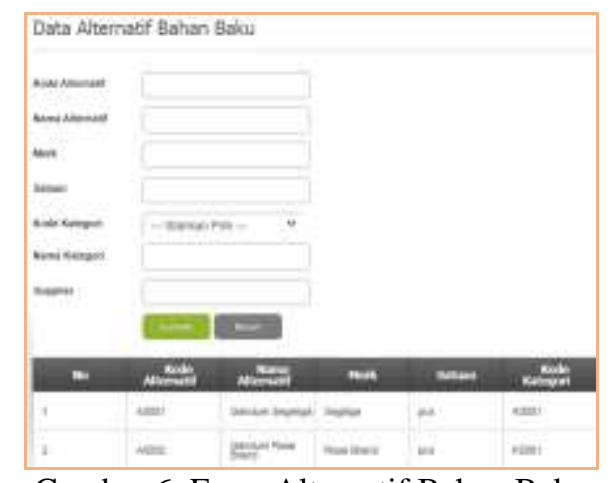

Form alternatif bahan baku merupakan form yang digunakan untuk memasukkan data alternatif bahan baku. Data alternatif merupakan data bahan baku yang dinilai sebagai objek penilaian sistem pendukung keputusan.

c. Form Pengadaan Bahan Baku

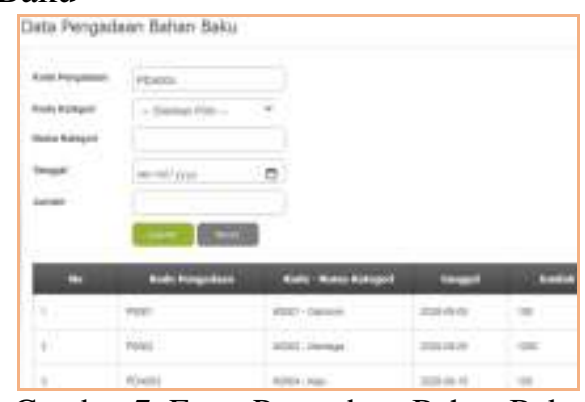

Keterangan :

Gambar 7. Form Pengadaan Bahan Baku

Form pengadaan bahan baku merupakan form yang digunakan untuk memasukkan data pengadaan bahan baku yang dibutuhkan untuk produksi roti.

\section{d. Form Kriteria TOPSIS}

Keterangan :

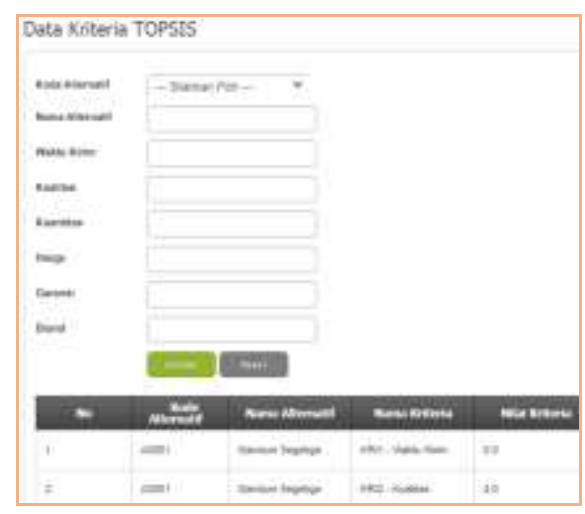

Gambar 8. Form Pengadaan Bahan Baku

Form kriteria TOPSIS merupakan form yang digunakan untuk memasukkan data bobot nilai dari kepentingan tiap-tiap kriteria yang dimiliki.

e. Form Preferensi 


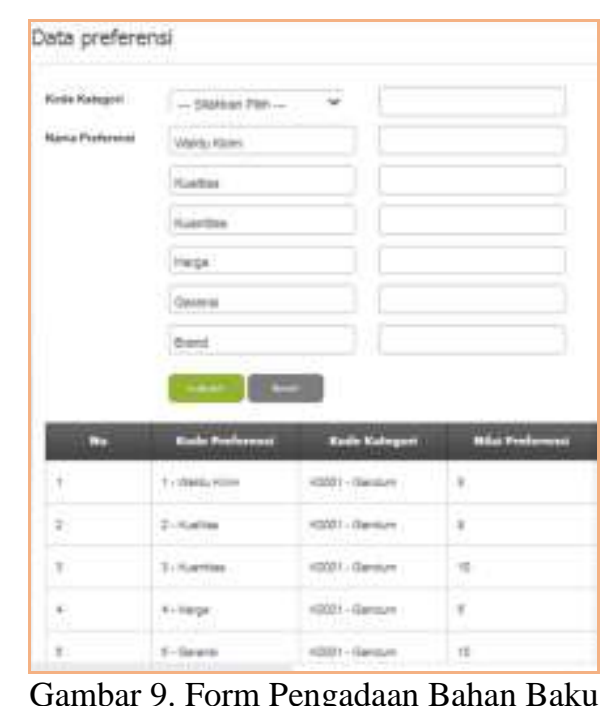

Keterangan :

Form preferensi merupakan form yang digunakan untuk data preferensi, yaitu nilai untuk memberikan nilai kepentingan dari kriteria pengadaan bahan baku.

\section{f. Form Matriks}

Keterangan :

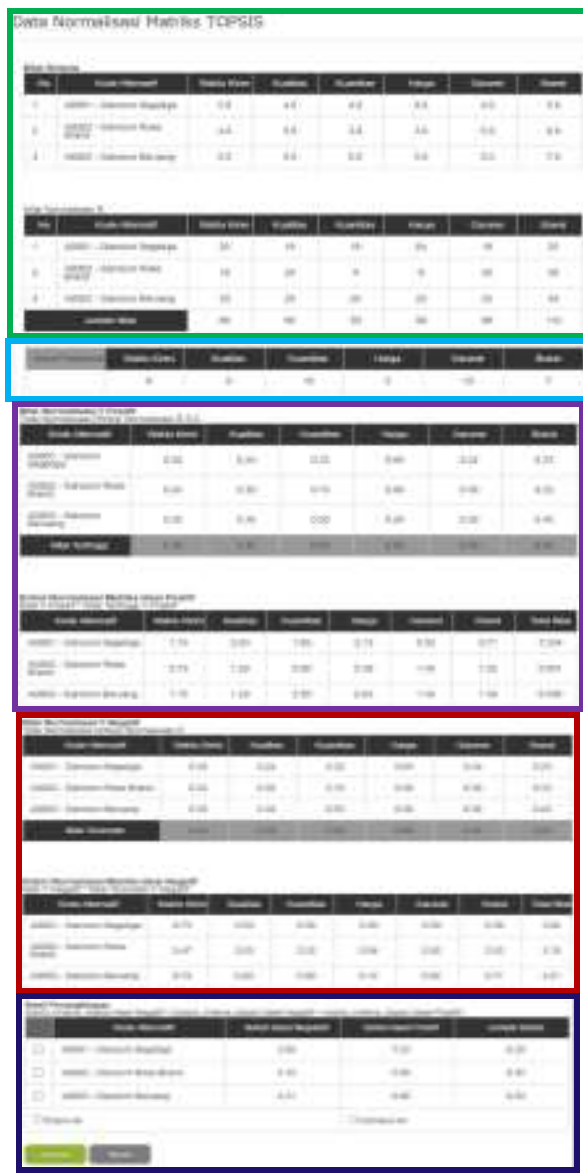

Gambar 10. Form Matriks Topsis

Tabel dengan (berwarna hijau) terdapat daftar nilai kriteria, yang terdiri dari waktu kirim, kualitas, kuantitas, harga, garansi, dan brand. Pada kolom waktu kriteria baris A001 Gandum Segetiga terdapat nilai kriteria 5.0

pada tabel nilai normalisasi R, pada kolom waktu kirim baris A001 Gandum Segetiga terdapat nilai normalisasi 25 . Nilai normalisasi ini dari nilai $5^{\wedge} 2=25$. 
Tabel bobot preferensi (berwarna biru) merupakan nilai bobot kepentingan antar kriteria.

Tabel Normalisasi Y Positif (berwana ungu) terdapat nilai pada kolom waktu kirim baris A001 Gandum Segetiga terdapat nilai normalisasi 0.38 merupakan nilai yang didapat dari $25 / 66$ dari tabel nilai normalisasi R.

Tabel Bobot Normalisasi matrik ideal positif, terdapat nilai pada kolom waktu kirim baris A001 Gandum Segetiga terdapat nilai normalisasi 1.15 merupakan nilai yang didapat dari $(0.38 * 0.38) * 8=1.15$ yang mana 0.38 pertama adalah nilai dari bobot di normalisasi Y positif * nilai tertinggi, dikali dengan nilai bobot preferensi.

Tabel Bobot Normalisasi matrik ideal negatif, terdapat nilai pada kolom waktu kirim baris A001 Gandum Segetiga terdapat nilai normalisasi 0.73 merupakan nilai yang didapat dari $(0.38 * 0.24) * 8=0.73$ yang mana 0.38 pertama adalah nilai dari bobot di normalisasi Y positif * nilai terendah dikali dengan nilai bobot preferensi.

\section{g. Form Hasil SPK}

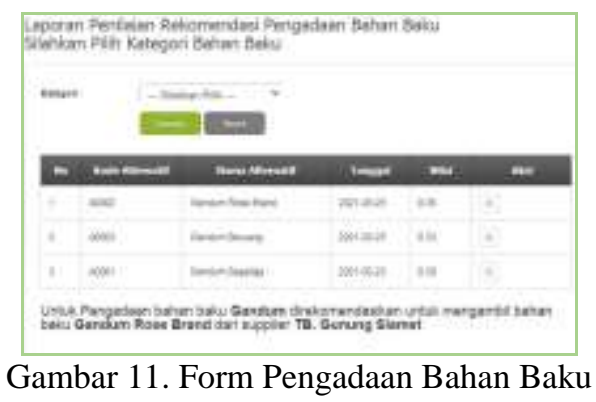

Keterangan :

Form hasil perhitungan dengan menggunakan metode Topsis, akan menampilkan hasil perhitungan dengan menampilkan rekomendasi penilaian untuk pengadaan bahan baku pembuatan roti.

\section{KESIMPULAN DAN SARAN}

Dari hasil penilaian dan uji coba produk, dapat disimpulkan bahwa :

a. Dalam penggunaan metode Topsis untuk sistem pendukung keputusan pengadaan bahan baku roti dapat digunakan untuk rekomendasi pengambilan keputusan dan bisa diterapkan di perusahaan.

b. Bahasa pemrogram PHP dapat di implementasikan dalam pembuatan SPK pengadaan bahan baku roti.

Hasil penilaian terhadap produk dari tenaga ahli atau pakar. Angket ini digunakan sebagai tingkat pengukuran sikap, pendapat dan persepsi perseorangan. Selanjutnya hasil data penilian angket dimasukan dalam skala penilaian adapun kriteria skala penilaian sebagai berikut :

Nilai 4 = sangat tepat/ sangat menarik

Nilai $3=$ tepat/ menarik/ layak/ sesuai

Nilai 2 = kurang tepat $/$ kurang menarik

Nilai $1=$ tidak tepat $/$ tidak menarik

Teknik analisis data yang digunakan untuk mengolah data nilai diperoleh dari penilaian sistem angket. Data kuantitatif dari setiap item dihitung dengan menggunakan teknik analisis rata - rata. Berdasarkan penjabaran diatas, dapat dirumuskan validasinya :

$$
\mu=\frac{\sum x}{n}
$$

\section{Keterangan :}

$$
\begin{array}{ll}
\mu & =\text { nilai rata- rata } \\
\sum_{\mathrm{N}} x & =\text { jumlah total nilai validasi } \\
& =\text { jumlah validator }
\end{array}
$$

Dengan kriteria penilaian validasi sebagai berikut:

Tabel 9. Kriteria Validasi

\begin{tabular}{cl}
\hline Nilai & \multicolumn{1}{c}{ Kriteria kevalidasian } \\
\hline $3,264-4,00$ & Sangat Valid \\
$2,51-3,25$ & Valid \\
$1,76-2,50$ & Kurang Valid (revisi)
\end{tabular}


$1,00-1,75 \quad$ Tidak valid (revisi total)

Serta rumus koefisienya :

$r=\frac{\mathrm{n}\left(\sum x y\right)-\left(\sum x y\right)}{\sqrt{\left[n \sum x^{2}-\left(\sum x\right)^{2}\right]\left[n \sum y^{2}-\left(\sum y\right)^{2}\right]}}$

Keterangan :

$r \quad=$ korelasi antara dua kelompok data

$\mathrm{x} \quad=$ data dengan menggunakan sistem baru

$\mathrm{y} \quad=$ data menggunakan sistem lama

Dengan kriteria penelitian efektif dan koefisien sebagai berikut :

Tabel 10. Kriteria Efektif dan Efisien

\begin{tabular}{cl}
\hline Nilai & \multicolumn{1}{c}{ Kriteria kevalidasian } \\
\hline $3,26-4,00$ & Sangat efektif \\
$2,51-3,25$ & Valid \\
$1,76-2,50$ & Kurang efektif (revisi) \\
$1,00-1,75$ & Tidak efektif (revisi total) \\
\hline
\end{tabular}

Hasil analisa data dengan pengisian angket berdasarkan skala nilai validasi,diketahui sebagai berikut :

Tabel 11. Hasil Pengisian Angket Oleh Pakar

\begin{tabular}{|c|c|c|c|c|c|}
\hline \multirow[t]{2}{*}{ No } & \multirow[t]{2}{*}{ Kegiatan Input } & \multicolumn{4}{|c|}{ Indikator } \\
\hline & & 1 & 2 & 3 & 4 \\
\hline 1. & Apakah bisa login dengan lancar & & & & $\sqrt{ }$ \\
\hline 2. & Apakah mudah mengoperasikan progamnya & & & & $\sqrt{ }$ \\
\hline 3. & Apakah perhitungan metode berjalan dengan tepat & & & & $\sqrt{ }$ \\
\hline 4. & Apakah bisa menghapus data dan menambahkan data & & & & $\sqrt{ }$ \\
\hline 5. & $\begin{array}{l}\text { Apakah progam memudahkan admin untuk menganalisa data } \\
\text { dengan baik }\end{array}$ & & & & $\sqrt{ }$ \\
\hline 6. & Apakah progam dapat menyimpan data dengan baik & & & & $\sqrt{ }$ \\
\hline 7. & $\begin{array}{l}\text { Apakah program berjalan dengan efektif dengan metode yang } \\
\text { digunakan }\end{array}$ & & \multicolumn{3}{|c|}{$\sqrt{ }$} \\
\hline & JUMLAH SKOR & & & & 24 \\
\hline & JUMLAH SKOR TOTAL & \multicolumn{4}{|c|}{3,8} \\
\hline
\end{tabular}

Sehingga dapat dihitung nilai validasinya :

$\mu=\frac{\sum x}{n}=\frac{27}{7}=3,8$

Berdasarkan perhitungan diatas, dapat disimpulkan bahwa hasil validasi dari pakar menunjukan nilai 3,8 berada diantara 3,26-4,0 yakni tergolong kategori sangat valid.

Tabel 12. Hasil Pengisian Angket Oleh User

\begin{tabular}{llcc}
\hline No & \multicolumn{1}{c}{ Kegiatan Input } & Indikator \\
& & 1 & 3 \\
\hline 1. & Apakah bisa login dengan lancar & $\sqrt{ }$ \\
2. & Apakah mudah mengoperasikan progamnya & $\sqrt{ }$ \\
3. & Apakah perhitungan metode berjalan dengan tepat & $\sqrt{ }$ \\
4. & Apakah bisa menghapus data dan menambahkan data & $\sqrt{ }$ \\
5. Apakah progam memudahkan user untuk menganalisa data dengan baik & $\sqrt{ }$ \\
6. Apakah progam menggunakan web responsif & $\sqrt{ }$ \\
7. & Apakah menu dapat di operasikan dengan baik & $\sqrt{ }$ \\
8. Apakah progam dapat menyimpan data dengan baik & $\sqrt{ }$ \\
9. Apakah progam berjalan dengan efektif & $\sqrt{ }$ \\
10. Apakah progam penghitung penentuan karyawan terbaik ini efektif untuk membantu & $\sqrt{ }$
\end{tabular}

JUMLAH SKOR

30 
Sehingga dapat dihitung nilai validasinya :

$\mu=\frac{\sum x}{n}=\frac{30}{10}=3,0$

Berdasarkan perhitungan diatas, dapat disimpulkan bahwa hasil validasi dari user menunjukan nilai 3,0 berada diantara 2,51 - 3,25 yakni tergolong kategori valid.

\section{DAFTAR PUSTAKA}

[1] Ismail Mulya Budiman," Sistem Pendukung Keputusan Pemilihan Karyawan Tata Usaha Biro Administrasi Universitas Nasional Menggunakan Metode Saw Dan Topsis", Jurnal Ilmiah Teknologi dan Rekayasa, Vol.25, No.2, pp.116-124, Agustus 2020

[2] Diana, 2018; "Metode dan Aplikasi Sistem Pendukung Keputusan", Yogyakarta: Deepublish,

[3] Gede Surya Mahendra, I Putu Yoga Indrawan, "Metode AHP - TOPSIS Pada Sistem Pendukung Keputusan Penentuan Penempatan Automated Teller Machine”, JST, Vol.9 no.2, pp. 130-135, Okt.2020

[4] Gilang Sonar Amanu," Pengembangan Sistem Pendukung Keputusan Pengadaan Dan Persediaan Barang Dengan Metode Perpetual Inventory Method Dan Economic Order Quantity", Jurnal Compiler, Vol.4, No.1, pp.21-30, Mei 2015

[5] M. Tabrani dan E. Padjiarti, "Penerapan metode waterfall pada sistem inventori PT. Pangan Sehat Sejahtera," Jurnal Infokar, vol.1, no. 2, hal. 30 - 40, Desember 2017.

[6] N. C. Resti, "penerapan metode simple additive weighting pada sistem pendukung keputusan pemilihan lokasi untuk cabang baru toko pakan ud. indo multi fish," Jurnal INTENSIF, vol.1, no. 2, hal. 102 - 107, Agustus 2017.

[7] Nur Ilmi Faisal," Analisis Sistem Pengadaan Barang Dan Jasa (Penunjung Langsung) Pada Di Dinas Pekerjaan Umum Dan Penataan Ruang Kota Manado", Jurnal Riset Akuntansi Going Concert, Vol.12, No.2, pp.1122-1132, Okt 2017.

[8] P. T. K. Adi, E. Sugiharti, dan Alamsyah, "Comparison between SAW and TOPSIS methods in selection of broiler chicken meat quality," Scientic Journal of Informatics, vol. 5, no. 1, Maret 2018.

[9] Putri Alit Widyastuti Santiary, "Sistem Pendukung Keputusan Penentuan Lokasi Wisata Dengan Metode Topsis", JTIIK, vol.5 no.5, pp. 621-628, Okt.2018.

[10] Putri Alit Widyastuti Santiary," Sistem Pendukung Keputusan Penentuan Lokasi Wisata dengan Metode Topsis", Jurnal Teknologi Informasi dan Ilmu Komputer, Vol.5, No.5, pp.621630, Oktober 2018.

[11] Siti Mahsanah Budijati," Sistem Pendukung Keputusan Untuk Pengadaan Bahan Baku Dinamis Dengan Adanya Diskon Dan Batas Masa Kadaluarsa”, Jurnal Informatika, Vol.4, No.1, pp.408-419, Januari 2020.

[12] Sunarti, "Perbandingan Metode Topsis Dan Saw Untuk Pemilihan Rumah Tinggal," Journal of Information System, pp. 69-79, Mei 2018.

[13] Taufik Kurnialensya and Rohmad Abidin, "Sistem Pendukung Keputusan Pelanggan Terbaik Dan Pemberian Diskon Menggunakan Metode Saw \&Topsis", ELKOM, vol. 13, no. 1, pp. 18-33, Jun. 2020.

[14] Taufik Kurnialensya and Yuli Fitrianto, "Sistem Pendukung Keputusan Penerimaan Karyawan Menggunakan Metode Saw (Simple Additive Weighting)", ELKOM, vol. 13, no. 2, pp. 118-128, Jan. 2021.

[15] Yustria Handika Siregar and Sri Rahayu, "Sistem Pendukung Keputusan Pemilihan Menu Makanan bagi Anak dengan Metode Analitycal Hierarchy Process (AHP)"; JTI, vol.2 no.1, pp.22-29, Jun.2018. 